\title{
LUIS EDUARDO AUTE Y SU TEMPLO DE EROTISMO
}

\author{
J. Ignacio DíEz \\ Universidad Complutense
}

Et comme elle se trouvait positivement dans sa niche, il n'eut pas loin à aller chercher le temple qu'il voulait desservir

MARQuis De SADE, Les 120 journées de Sodome

[...] su espíritu es la hostia de mi amorosa misa [...] en ella hay la sagrada frecuencia del altar

RUBÉN DARÍO, «Ite, missa est»

\section{Un erotismo auténtico}

Para cualquier seguidor de la trayectoria de Luis Eduardo Aute como cantante no es ningún secreto que sus letras beben en un erotismo propio, alejado de los tópicos. Es fácil recordar el estribillo de «No te desnudes todavía,/espera un poco más»' , célebre en una época que también se hizo célebre precisamente por la tendencia contraria, la que postulaba un destape que se extendió, benéfico e injustificado, por buena parte de la filmografía española de los setenta y los ochenta del siglo pasado.

${ }^{1}$ L. E. Aute, Días de amores. Las mejores canciones de amor, Santillana, Madrid, 2006, págs. 51-52. 
El erotismo de la prolífica producción de Aute es, sin lugar a dudas, de signo muy distinto al habitual y llega hasta ahora mismo, cuando en una inspirada canción sobre la web trata del «sexo al estilo neanderthal»»2. Sin duda Aute canta al amor, para algunos el tema central de sus letras ${ }^{3}$, con sensibilidad y erotismo, con los característicos juegos de palabras de toda su discografia, con un sentido lírico o poético muy finamente apreciable: desde «Dentro» ${ }^{4} \mathrm{y}$ «Anda» ${ }^{5}$ hasta «Mojándolo todo $»^{6} \mathrm{O}$ «Luz contra luz» ${ }^{7}$, por citar un puñado de ejemplos. Incluso en textos de marcado pesimismo, como «A día de hoy» («que vivir fue otra forma de estar muerto») 8 la voz cantante encuentra el único amarre en «que solo sé quien soy/cuando estoy/dentro de ti»». En esta misma canción, tomada como emblema de una suerte de marca de la casa, el acercamiento al erotismo trata de evitar los lugares comunes y quiere insistir en otros silenciados o incógnitos, y Aute lo consigue con creces en su obra ${ }^{10}$. Pero, probablemente, el más sostenido acercamiento al erotismo tiene lugar en un mítico doble LP titulado Templo, que cuenta con casi treinta años y que posee su propia leyenda ${ }^{11}$.

\section{Historia e historias de Templo}

El álbum se vendió en dos formatos distintos: uno, el de los dos discos unidos por una doble carátula; otro, en un cofre que recogía, además, entre

\footnotetext{
${ }^{2}$ L. E. Aute, «Na de na», A día de hoy, Sony-BmG, Madrid, 2007.

3 «De entre todos los temas que han reclamado la atención de Aute el amor ha sido el más transitado» (E. la Hoz, «Prólogo: es porque existes», en L. E. Aute, Días de amores, pág. 7). Claro que Aute afirma: «el único argumento de mis canciones, de mis textos y de mi pintura es el ser humano», «Luis Eduardo Aute, cantautor, poeta y pintor: "Todos los seres vivos tienen alma"», Escritura pública, 39, 2006, pág. 61. Y, poco después: «El sexo es el motor del mundo. El amor es un invento del ser humano para engañarse a sí mismo», pág. 62 .

${ }^{4}$ L. E. Aute, Días de amores, págs. 19-20; la interpretación de Silvio Rodríguez en Entre amigos, Movieplay, Madrid, 1983.

${ }^{5}$ L. E. Aute, loc. cit., págs. 39-40; la interpretación de Pablo Milanés en Entre amigos («seamos un cuerpo/enamorado»). después.

L. E. Aute, loc. cit., págs. 131-132, que incluye también la cita de Éluard que menciono

${ }^{7}$ L. E. Aute, loc. cit., págs. 163-164.

8 «A día de hoy», en el CD homónimo.

${ }^{9}$ L. E. Aute, Días de amores, pág. 177.

10 «Con paciencia y con saliva/se tiró un elefante a una hormiga/muerta/la más triste historia de amor/o no», L. E. Aute, Volver al agua. Poesía completa (1970-2002), Sial, Madrid, 2002, pág. 29.

11 Templo, Ariola, Barcelona, 1987. Agradezco a Luisa Fernanda Aguirre de Cárcer la muy oportuna conversión en formato MP3. En Días de amores, se recogen seguidas varias canciones del álbum: «Aleluya (no. 5)», «Ángelus», «No soy digno», «Por donde levitas», «Cada vez que me amas», «Descendimiento» y «Éxtasis de ángeles caídos» (págs. 89-101).
} 
otras cosas, los cuadros de Aute sobre el tema ${ }^{12}$. En el formato más sencillo, al abrir el álbum, se ven no solo las fotografías de los intérpretes y colaboradores (entre ellos una jovencísima Natalia Millán), sino también un conjunto de citas o «jaculatorias» que supuestamente, según la invitación que las precede, proporcionan «indulgencias absolutamente plenarias» (o, sin que se indique, sirven de mantra para el amor) ${ }^{13}$. Algunas son sólidos e inspirados fragmentos, como la cita que se atribuye a Fernando Savater: «... somos la herida...». Todas ellas revelan una voluntad que quizá no se pueda deducir del en principio enigmático título del álbum: Templo. El religioso rubro podría remitir, sin escuchar ninguna canción, a una suerte de conversión oportuna y seguramente necesaria en un país tan católicamente católico como el nuestro. Pero «templo» es un término del que no puede apropiarse solo el catolicismo, ni siquiera el resto de las confesiones cristianas. Para el Diccionario de la lengua española, de la $\mathrm{RAE}^{14}$, un templo es un «edificio o lugar destinado pública y exclusivamente a un culto» y también un «lugar real o imaginario en que se rinde o se supone rendirse culto al saber, a la justicia, etc.». En ese etcétera final cabe, y muy cómodamente, el erotismo. El Diccionario de Autoridades, como siempre, es más completo y sugerente:

Edificio dedicado a Dios y en que se da culto a los santos. Generalmente se llama también cualquiera de los lugares dedicados a los falsos Dioses de la Gentilidad. Metafóricamente se llama el alma santa, porque Dios mora en ella por la gracia ${ }^{15}$.

La portada de la edición básica se ilustra con un óleo de un pie herido y sangrante, posiblemente horadado, y que en la tradición cristiana podría remitir a los efectos de la crucifixión (en Transfiguraciones, se titula «Al fin») ${ }^{16}$. Junto a él un rostro parecería querer lamer la herida. ¿Alguien lamió las heridas de Cristo? ${ }^{17}$ Lamer es un término muy propio de la erótica... mientras que limpiar las heridas parece más propio de la tradición bíblica, así como limpiar los pies de Cristo (e incluso, por increíble que parezca, secarlos con una buena mata de cabello femenino). El óleo sirve, entre otras cosas, para demostrar que la tradición cristiana acepta las conexiones eróticas, quizá malgré elle, lo que podría llevar a pensar, una vez instalados en esa línea que trata de seguir el

12 Ahora pueden contemplarse en Transfiguraciones. Museo Nacional de Bellas Artes de Cuba, 20 de marzo-2 de junio de 2008, Sociedad Estatal para la Acción Cultural Exterior de España, ¿Valencia?, 2008, págs. 59-78.

${ }^{13}$ Otras citas, de mucho interés, abren «El universo» (L. E. Aute, Días de amores, pág. 81): «En pleno delirio sexual, cualquiera tiene derecho a compararse con Dios» (Cioran) y «... sexo líquido universo de licor...» (Paul Éluard).

${ }^{14} \mathrm{http}: / /$ www.rae.es/rae.html (consulta del 6 de mayo de 2016).

$15 \mathrm{http}: / /$ buscon.rae.es/ntlle/SrvltGUILoginNtlle (consulta del 22 de septiembre de 2011).

${ }^{16}$ Transfiguraciones, pág. 75.

${ }^{17}$ A Lázaro «hasta los perros venían a lamerle las úlceras» (Lucas 16: 21; todas las citas de la Biblia proceden de la versión de E. Nácar Fuster y A. Colunga Prieto, BAC, Madrid, $\left.{ }^{35} 1977\right)$. 
trazado de la deseable coherencia, en las hipotéticas conexiones eróticas de la liturgia católica. ¿Alguien se ha sentido erotizado leyendo la Biblia, visitando una iglesia o asistiendo a una misa? Cualquiera de estos tres elementos tan dispares puede proyectar un vector cargado de futuro, aunque seguramente para muchos, para el núcleo duro y radical del asunto, hasta la simple pregunta constituye un sacrilegio. En todo caso la pregunta me sirve para aludir al interesante tema de las relaciones entre erotismo y sacrilegio, bien conocidas y muy intensamente desarrolladas en los escritos del marqués de Sade, por ejemplo. Las razones de la fértil conexión de erotismo y sacrilegio sin duda son complejas $^{18}$, aunque algunas son fáciles de intuir, por lo que no me detengo en ellas. Más me preocupa adentrarme en la cuestión de si realmente existe una relación entre ambas, más allá de la provocación o de la subversión de los valores tradicionales o burgueses. En la trasera de la edición básica de Templo se reproduce el óleo «Tengo sed» ${ }^{19}$, donde una boca, sin duda sedienta, está justo al lado de un pezón femenino; unas posibles manos de mujer parecen acercar esa boca al pezón para darle de beber, mientras dos dedos de la otra mano rodean el mismo pezón en una postura característica para facilitar la tarea al que mama.

Las letras de Templo proceden del libro, del mismo autor, Templo de carne (1986), y mantienen una estrechísima relación con una exposición de pintura sobre el mismo tema ${ }^{20}$. Para los seguidores del cantante tampoco es una sorpresa que Aute sea un artista multifacético, pues es músico, cineasta, poeta y pintor, entre otras cosas. Sin embargo, en el álbum nada se dice del libro o de la exposición, al menos en el doble LP, si bien esta última se deja presentir por las reproducciones. Quienes con menos recursos se acercaron a Templo tienen que utilizar la web para encontrar declaraciones como la que afirma que el cantante puso música a los poemas de Templo de carne, «inspirado en una serie de óleos que elaboró para una exposición en Madrid, los cuales "reflexionaban sobre la dimensión poética de la pintura religiosa: la gran pintura erótica es la gran pintura religiosa. Creo que si Dios existe sería sexo puro, que no puro sexo" |\rangle$^{21}$. La cita tiene todos los ingredientes para ser auténtica, como sabe cualquier seguidor de Aute. Pero más que un nuevo Cantar de los cantares, como afirma el bloguero, aserto muy discutible sobre el sentido de Templo, lo que me interesa es subrayar la consciente y explícita relación entre erotismo y pintura religiosa, pues de ese nexo se da fácilmente un salto a los textos religiosos. Según Aute, en la misma web, Templo es:

18 Un planteamiento amplio sobre la tradición erótica y sus componentes en J. I. Díez, $L a$ poesía erótica de los Siglos de Oro, Laberinto, Madrid, 2003; J. I. Díez y A. Cortijo, «Erotismo y erotismo áureo: tendencias de un fértil dominio», eHumanista, 15, 2010, págs. i-xxv.

${ }^{19}$ Transfiguraciones, pág. 71.

${ }^{20}$ Templo (1987), en Transfiguraciones, pág. 59 y sigs.

$21 \mathrm{http} / / /$ sobrasescogidas.blogspot.com/2007/08/luis-eduardo-aute-templo.html (consulta del 6 de mayo de 2016). 
[...] el disco que más aprecio [...] el más experimental que he hecho y es también el disco maldito, el que no pude terminar. Creo que es un disco que se reconocerá con el paso del tiempo. Lo quiero mucho porque no me lo dejaron terminar. Me dijeron que esa locura no podía llegar más lejos...

Sin embargo, ese malditismo queda matizado por el autor cuando afirma, durante la celebración del I Congreso Internacional La Letra de la Música22, que lo que faltaba era pulir los arreglos, limitar la extensión de algunas canciones, etc., pero que no se han excluido textos ni se ejerce sobre ellos ninguna clase de censura de la discográfica o autocensura. De hecho, el libro también tiene dieciocho poemas, aunque en otro orden.

Dieciocho no es un número iniciático, ni parece simbolizar nada concreto, al menos hasta donde alcanzo. Frente a las viejas tradiciones de la historia literaria aquí la supuesta magia de los números no descansa en cantidades ya muy explotadas (las divisiones trinitarias, las alusiones a las estaciones, a los planetas - del «perfume de los planetas» me ocupo luego-, los meses del año o el número de apóstoles, etc.). Sin embargo, el conjunto de los dieciocho poemas sí que busca una unidad temática a través de distintos juegos y referencias sobre el cristianismo y las ceremonias e instituciones católicas. Se perciben con claridad una apertura y un cierre en Templo: el último corte, el dieciocho, es «Transfiguraciones» (mientras en Templo de carne el final es «Perderme, al fin», que se corresponde con el corte diecisiete, «Al fin» ${ }^{23}$; vuelvo más tarde sobre la doble conclusión del álbum). Lo significativo es, creo yo, por un lado, la inevitable voluntad de ordenación en uno y otro caso de dieciocho piezas, muy diferentes en extensión y en reminiscencias culturales o religiosas; por otro, la posibilidad de que esos órdenes intenten aproximarse a otra cosa: ¿se trata de una nueva versión del Cantar de los cantares? Lo dudo mucho. ¿Es una parodia de la misa? Lo dudo aún más. ¿Un «via crucis amoroso»?? ${ }^{24}$ No lo creo tampoco. En mi opinión es un ciclo, nada mágico por el número, cuya disposición sí comparte un inicio («El verbo se hizo carne»), esencial para abrir el planteamiento del templo de la carne. Pero no parece perseguirse una imitación o parodia de una estructura preexistente, aunque en la distribución sí se comunica un ambiente religioso, como ocurre con las voces de «Transfiguraciones», que en el libro se reconoce un cadáver exquisito a seis manos (las de Jaume Sisa, Pau Riba y Luis Eduardo Aute). Seguramente se podría argumentar sobre la función de cierre de las citas en el libro, que

22 Celebrado en Madrid, en la Universidad Rey Juan Carlos, del 21 al 23 de septiembre de 2011.

${ }^{23}$ En la sección Templo, de Transfiguraciones, los diez óleos curiosamente aparecen en otro orden y acompañados, tras «Salvación de la carne», de Savater, de los poemas: «Aleluya n. 5», «Lágrima de sangre», «No la boca sino el beso», «Irreversiblemente», «Tengo sed», «El sagrado perfume», «Al fin», «No soy digno I y II», «El verbo se hizo carne»; los tres últimos sin poema (págs. 59-78), todos ellos con escorzos, pezones, vellos púbicos y sangre. También hay poemas (todos muy breves) y dibujos a lápiz sobre papel (mucho más abiertamente eróticos) en Angelingua (1996), Transfiguraciones, págs. 89-105.

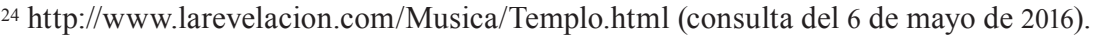


también se recogen en el interior del álbum (con otro rol estructural). El caso es que, en Templo de carne, tras el último y significativo verso («al fin»), se copia el «Breviario de citas», precedidas por una recomendación: «La lectura repetida de las siguientes jaculatorias proporciona indulgencias absolutamente plenarias ${ }^{25}$. La parodia y el humor son aquí esenciales, al final, ¿para desmontar una posible lectura mística? Las citas son todas ingeniosas y se atribuyen a Leonard Cohen, Buñuel, Lezama Lima, Vicente Gallego («Tú, templo irrenunciable entre pasiones y renuncias»), Azúa, Bowie, Savater, Fuentes y Novalis. Referencias nada sacras, o bien solo sacralizadas, en esta exquisita mezcolanza, por la cultura popular.

\section{Escuchar/leer Templo}

Templo se abre con uno de los juegos característicos de Aute, con esa broma basada en el evangelista sobre el verbo y la conjugación, tan sacrílega seguramente, aunque lo más interesante es la transformación en dos carnes: «El verbo se hizo carne/tuya/y carne mía/y conjugó entre nosotros» ${ }^{26}$. La carne es el elemento esencial de este templo y es, al mismo tiempo, el factor que va a explotar para marcar una enorme distancia sobre la tradición católica. Aute se apropia de un sistema referencial muy conocido y muy compartido para crear otro, a veces diametralmente opuesto: «Acudo/a tu templo de carne/como quien va a misa/dispuesto a oficiar/la ceremonia de la Consagración».

El libro, de título más explícito, se publica un año antes ${ }^{27}$. En los poemas se hace evidente la subversión del discurso religioso, pues se apoyan en esta equivalencia: templo = cuerpo femenino. Para cualquier cristiano, convencido o inducido desde el nacimiento, hay una base reconocible, pues el cuerpo humano es un templo: «¿O no sabéis que vuestro cuerpo es templo para el Espíritu Santo, que está en vosotros, y habéis recibido de Dios, y que, por tanto, no os pertenecéis?» (1 Corintios 6: 17). Aute, sin embargo, prefiere explicitar la conexión romántica, anteponiendo unos versos de Novalis: «No hay más que un templo/en el universo/y ese es el cuerpo humano. / Nada hay más sagrado que esa forma elevada» ${ }^{28}$. La equivalencia aparece transformada (o sesgada, si se prefiere), pues Aute convierte la valoración del cuerpo humano en una exaltación del cuerpo femenino. La carne femenina como templo puede recordar,

${ }^{25}$ También se copian, con las mismas indicaciones, en Templo.

26 «Y el Verbo se hizo carne y habitó entre nosotros» (Juan 1: 14). Obsérvese la interesada variación que ofrece el Angelus: «V. El Verbo se hizo hombre./R. Y habitó entre nosotros» (http://oficiodivino.com/angelus.htm, consulta del 6 de mayo de 2016).

${ }^{27}$ Es el tercer y último libro recogido en L. E. Aute, Volver al agua, con prólogo de F. Savater (págs. 121-149).

${ }^{28}$ Muy curiosamente, en Templo de carne (que incluye las citas al final), el ciclo también se cierra con una cita de Novalis: «Lo que yo siento por Sophie no es amor, es religión» (L. E. Aute, Volver al agua, pág. 150). 
a los impenitentes lectores de Rubén Darío, a la «celeste carne de la mujer». Por ese camino se llega con facilidad a convertir el cuerpo femenino, o una parte de él, en un altar (véanse las dos citas que abren este trabajo, de Sade y de Rubén Darío, y esta del propio Aute en Templo: «Y me acerco/a tu altar de transubstanciaciones/divino alimento humano», de «Éxtasis de ángeles caídos»).

El poemario, como el disco, apoya todo su sólido volumen en el transparente juego de un nuevo tú que reemplaza al de la tradición cristiana: «tú» ya no es «Dios», sino «tú, mujer», y así los poemas edificados con la argamasa religiosa realmente levantan un monumento netamente amoroso. No se trata, como podría pensar alguno (traspasado por las pasiones de los estudios culturales), de que Dios se haya convertido en mujer (aunque quizá es inevitable una cierta divinización de la destinataria), sino de transformar un referente tan marcado de la literatura religiosa (en ese repetido diálogo de un yo sufriente y humilde frente a un tú divino y silente) en una destinataria de flesh and blood. A partir de esa conversión fundamental y radical, Templo dispone otra transformación extraordinariamente lograda que consiste en reutilizar los elementos de la liturgia o la fe católica (como la corona de espinas, la transfiguración, la sangre, etc.) dentro de un nuevo discurso, que teje esa nueva relación esencial: no la del hombre y Dios (con el habitual détour sobre la redención o salvación del ser humano), sino la del hombre y la mujer, un hombre que habla a la mujer, silenciosa, con el sistema comunicativo cristiano convertido en una red metafórica de gran rendimiento, pues cualquier oyente conoce esas referencias, ahora reutilizadas y cargadas de nuevos valores. Los ejemplos son infinitos, como la arena del mar o como el agua del mar, y pretender trasladarlos a un recipiente pequeño es imposible. Selecciono uno, por tanto, y como ilustración. La cuestión de ser o no ser digno de entrar en el templo, de la canción «No soy digno», transforma el decir evangélico ${ }^{29}$ y se carga de un neto contenido erótico, apoyado en la equivalencia de Templo = cuerpo femenino (por lo sagrado, por la adoración, por la paz y la reflexión, etc.) y en las connotaciones eróticas que destila, en este contexto, «entrar» ${ }^{30}$.

No dispongo de espacio para analizar en detalle las dieciocho piezas, por lo que me detendré en cinco, cuatro de ellas auténticamente centrales: "Aleluya n. 5 » (corte dos), «Éxtasis de ángeles caídos» (corte cinco), «Tengo sed» (corte once) y «Cada vez que me amas» (corte catorce). En todas ellas se percibe nítidamente la técnica constructiva u organizativa del álbum, que pasa, como decía, por la reorientación de términos (mejor que de metáforas o de imágenes, aunque

29 «Señor, yo no soy digno de que entres bajo mi techo; di solo una palabra y mi siervo será curado», Mateo 8: 8. Compárese también con «Que tus fieles, Señor, te aclamen al entrar en tu morada», «Vísperas del Jueves, III semana del salterio», http://www.oficiodivino.com/vispoj3. htm (consulta del 6 de mayo de 2016); y con Salmos 132: 3-5: «No entraré en la tienda de mi casa ni subiré al lecho de mi descanso; no daré a mis ojos el sueño ni reposo a mis párpados mientras no halle un lugar para Yavé y una morada para el Poderoso de Jacob».

${ }^{30}$ Poesía erótica del Siglo de Oro (ed. de P. Alzieu, R. Jammes e Y. Lissorgues), Crítica, Barcelona, 1984. 
también de las segundas) propios del lenguaje cristiano. Así en el «Aleluya n. 5» (género, con sus numeraciones, tan característico de Aute) se acumula un vocabulario reconocible de la tradición cristiana, como «tentarme», «condéname», «flagélame», «la corona de espinas», «enjúgame el sudor y las lágrimas», «mi cuerpo en sacrificio», «crucifícame», etcétera:

\section{Aleluya n: 5}

Llévame contigo a la cumbre más alta para tentarme con mil ciudades de oro y carne que pondré a tus pies. Aparta de mí tus labios, son puñales sus palabras traidoras; acércame todos sus besos que me matan dulcemente en el silencio. Condéname por los siglos de los siglos a vivir clavado a tu cuerpo apasionado, así podrán nuestras almas redimirse de la condena eterna.

Flagélame si merezco penitencia, somos la herida; mis llagas serán los surcos que encauzarán tus iras.

Ponme, si es nobleza lo que obliga, la corona de espinas,

la sangre que mane de mis sueños purificará tus pensamientos.

Enjúgame el sudor y las lágrimas con tu mirada, que quede eternamente en tus pupilas grabado el rostro de quien más te amó.

Si no supone una cruz sobre tus hombros, ayúdame a soportar este ingrávido peso que me aferra al centro de tu gravedad.

Expóliame, si el deseo te lo exige, desnúdame ante ti; te ofreceré mi cuerpo en sacrificio de amor y muerte.

Crucifícame, si no te tiembla el pulso, crucifícame; pero hazlo con los clavos de tus ojos, con los golpes de tu corazón.

Recógeme en tu regazo cuando caiga, te lo suplico;

junto a tu vientre consumado, mi bien amada, te encomendaré mi espíritu.

Aleluya. 
Un simple vistazo permite notar la conexión con la pasión de Cristo, en casi todos los casos. El torturado cuerpo de Cristo posibilita el desplazamiento hacia prácticas carnales y apoya una doble identificación insólita: Dios-Cristo = Amada-el poeta, a veces dirigida por ligeros pero decisivos retoques de la tradición (como en el proceso de la tentación que se basa en «mil ciudades/de oro y carne que pondré a tus pies»; la cursiva es mía) ${ }^{31}$. Por otra parte, todo el poema-canción está atravesado por elementos corporales o físicos («carne», «pies», «labios», «besos», «carne apasionada», «herida», «llagas», «sangre», «sudor», «lágrimas», «pupilas», « rostro», «hombros», «cuerpo», «ojos», «corazón», «vientre»). La remisión, insistente sin duda en lo físico, se entrecruza con la reformulación de alguno de los mitos católicos: «condéname por los siglos de los siglos / a vivir clavado a tu carne apasionada» o «expóliame, si el deseo te lo exige, / desnúdame ante ti; te ofreceré mi cuerpo en sacrificio» o la crucifixión que conviene hacerla «con los clavos/de tus ojos, con los golpes/de tu corazón» antes de «encomendar mi espíritu» no en un lugar mejor que «junto a tu vientre consumado». Es importante calibrar el efecto de lo que podría parecer una sacrílega mezcolanza con una melodía sobre la que se repite «aleluya».

Un auténtico tour de force se desarrolla en «No soy digno» (corte cuatro), donde el juego erótico depende del clásico «entrar», que subvierte, como decía antes, el pasaje bíblico. El poema refuerza la idea de una unión sagrada, y se adentra en el tópico de la dignidad del templo de Dios. Lo que desde luego no se encuentra en la tradición cristiana es una nueva y revolucionaria identificación, aunque bien conocida de la otra tradición, la erótica: coño = paraíso: «No soy digno, mujer,/no soy digno/de entrar en tu morada;/no debe ser el Paraíso/cueva para el ladrón/encarcelado». En este inicio Aute se muestra deudor del arsenal expresivo del erotismo que se conforma en torno a la metáfora de «cueva» o a la imagen del «encarcelamiento». Un tejido complejo que permite a la voz masculina y cantante expresar su futuro deseo de que «no querré salir de ella/nunca». Para ello, para poder entrar, se fija una insólita condición: que la amada lo pida «indignada». Por último, todo el proceso, para aviso de incautos (si los hay), se conecta con el mandato divino de «amarás al Señor, tu Dios, con todo tu corazón, con toda tu alma, con todas tus fuerzas y con toda tu mente, y al prójimo como a ti mismo» (Lucas 10: 27), uno de los mandamientos-resumen y por ello de una importancia capital ${ }^{32}$, aunque aquí ese amor se concreta en clave heterosexual: «si me amas, como yo te amo/ sobre todas las cosas»».

Central es también el corte número cinco que remite a un episodio bíblico muy conocido ya desde el título y que, al mismo tiempo, enlaza con una carnalidad

31 «De nuevo le llevó el diablo a un monte muy alto, y mostrándole todos los reinos del mundo y la gloria de ellos, le dijo: todo esto te daré si de hinojos me adorares», Mateo 4: 8.

32 «Amarás al Señor, tu Dios, con todo tu corazón, con toda tu alma y con toda tu mente. Este es el más grande y el primer mandamiento. El segundo, semejante a este, es: Amarás al prójimo como a ti mismo. De estos dos preceptos penden toda la Ley y los Profetas», Mateo 22: $37-40$. 
tan potente que es capaz de atraer a esos seres espirituales que sacrifican por la carne la propia eternidad:

\section{Éxtasis de ángeles caídos}

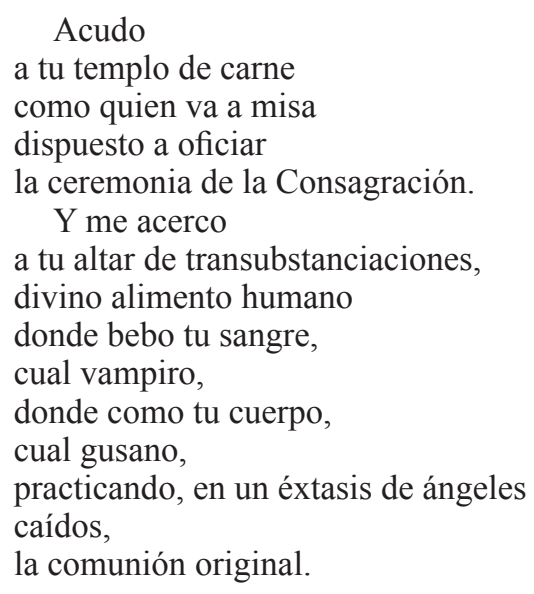

Podría tratarse de un recuerdo de la leyenda recogida en el Génesis sobre los ángeles que abandonan su condición angélica para unirse a las «hijas de los hombres» (6: 1-4), pero también podría ser un rótulo general, propio del malditismo, donde el «ángel caído» es una suerte de institución (que se conecta también con la idea de rebeldía). En todo caso, el texto se configura con una marca inequívocamente sexual que es el «éxtasis». El término, a estas alturas, invita a preguntarse al lector o al oyente por el éxtasis en la Biblia: ¿quiénes lo experimentan y cuándo? Aunque podría pensarse que en el inspirado libro no se alude a un éxtasis sexual, no es así, por más que no se haga precisamente en el pasaje de los ángeles caídos, pues constituiría una suerte de propaganda perniciosa para los intereses de los autores del libro. Sin embargo, al recomendar con fuerza el matrimonio se puede leer lo siguiente sobre la embriaguez que puede comportar: «Bendita tu fuente, y gózate con la mujer de tu mocedad. Cierva carísima y graciosa gacela; embriáguente siempre sus amores y recréente siempre sus caricias» (Proverbios 5: 18-19). En el poema de Aute la equivalencia templo=cuerpo femenino es evidente, e incluso se precisa más, puesto que dentro de ese templo hay un «altar de transubstanciones, / divino alimento humano» y, en ese contexto, en medio de la sangre y el cuerpo, se produce una «comunión original». Quizá para los expertos en el tema cabe aquí la idea más pura de sacrilegio; para los que no lo somos, las imágenes componen un retrato bien conocido de la erótica. También para otros expertos, podría caber aquí la idea de misticismo. Sin embargo, en mi opinión Aute señala cuál es la «comunión original» y dónde y cómo se produce: carne y sangre, sí, un alimento humano que es divino, aunque como diría Nietzsche, es humano, 
demasiado humano. ¿Alguien ha comparado el cuerpo y la sangre de Cristo con el intercambio y fusión de la «bestia rosa», como diría Francisco Umbral en su espléndido libro homónimo? El trenzado de las sólidas imágenes eróticas pierde conscientemente un cierto espesor al incluir dos notas divertidas o extrañas al menos, como son las referencias al «vampiro» y al «gusano». Ambas creo que inequívocamente rechazan la supuesta visión mística y la acercan a una devoración física, carnal, por más que extática. Los ángeles caídos son, sin lugar a dudas, los humanos. ¿Son los actos sexuales, en cualquiera de sus formas, un reconocible resto de esa condición angélica? ¿Suponen una reminiscencia de la «condición original»? ¿Se remite a ella de algún modo por la consecución del éxtasis?

En «Tengo sed» (corte once) tocamos otro highlight, que sutilmente recuerda un conocido episodio evangélico, cuando Jesús pide de beber a una mujer en un pozo (quizá también reverbere aquí la «sed de justicia y salvación» y ila sed de conocimiento? Desde luego la «sed de agua de vida»): es, en todo caso, un motivo muy cristiano.

\section{Tengo sed}

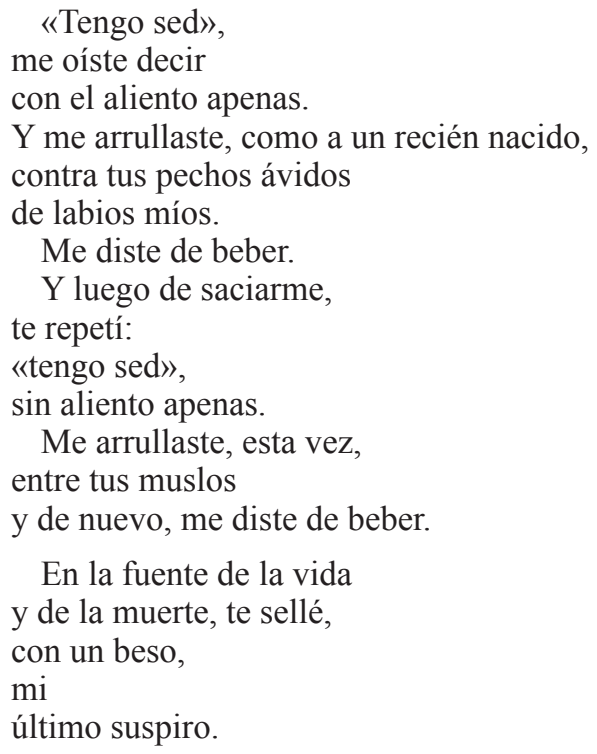

Con la auténtica originalidad de Aute se retoma la conocida historia evangélica de un Jesús que tiene sed y le pide de beber a una mujer, a una samaritana, al borde de un pozo (Juan 4: 6-28). Aquí la voz masculina reelabora una historia en la que se bebe dos veces, de dos fuentes distintas e igualmente femeninas. Aunque ambas fuentes confluyen al final del poema y se confunden en una («la fuente de la vida/y de la muerte»), el texto sugiere, con toda 
claridad, que el amante bebe de los pechos de la amada y bebe también «entre tus muslos». Mientras en el evangelio el episodio le sirve a Jesús para ilustrar la importancia de un agua de vida que quita para siempre la sed, en la canción de Templo el erotismo explícito señala dos lugares decisivos en el erotismo heterosexual para acabar en un final ambiguo, aunque muy climático. ¿De qué suspiro se trata en ese «último suspiro»? ¿Es el de la muerte, es el de la «la petite morte», es un homenaje a Buñuel? ${ }^{33}$ El beso como tema erótico es central en Templo y aquí ese beso sirve para «sellar» una herida y una fuente.

En Templo hay una sutil variación en la letra. Sobre una música que podría definirse como espiritual se escucha una voz femenina que muy suavemente desgrana los mismos versos, aunque cambia el punto de vista, pues los pronombres son otros: «te oí decir», «contra mis pechos ávidos / de labios tuyos», «te di de beber», etc. Dos variantes son «volviste a repetir»y «el/último suspiro». Es evidente la voluntad de quebrar aquí la apropiación de la voz masculina, que se rompe solo para escuchar el reflejo de la misma historia desde la voz de la amante. La quiebra de la unidad que mantiene Templo de carne probablemente busca una variación y un efecto más intensamente erótico: «te arrullé, esta vez/entre mis muslos/y de nuevo, te di de beber».

El último paso de mi selección se halla en «Cada vez que me amas» (corte catorce) que subvierte la idea de «milagro»: amarse, cada vez, es el milagro, aunque conviene usar los pronombres adecuados.

\section{Cada vez que me amas}

Tu sed transubstancia mi sudor en vino que bebemos en cada beso.

Tus pies no se hunden en los lagos de mis lágrimas.

Tu saliva siembra la luz en la noche de mis ojos.

Tu voz resucita mis músculos dormidos mis latidos sepultados.

Tus manos, cuando me tocan, curan mis heridas más invisibles.

Tu hambre fecunda peces que se multiplican como deseos de humedad en el múltiple pan de mi cuerpo.

Cada vez que me amas, es un milagro.

Como en los demás poemas de Templo se trata de una celebración del amor físico, en esta ocasión convertido (¿elevado?) a la categoría de milagro, por su exaltación, por su exultación... ¿por su rareza?, por su intensidad, etc. El poeta persigue con pluma firme diversos milagros atribuidos por los evangelistas

\footnotetext{
${ }^{33}$ L. Buñuel, Mi último suspiro (trad. de A. M. de la Fuente), Plaza \& Janés, Barcelona, 1986.
} 
a Jesús, de modo que se alude a la conversión del agua en vino en las famosas bodas de Canaán, a una célebre caminata de Jesús sobre las aguas, a la devolución de la vista a un ciego, a la resurrección de Lázaro, a la imposición de manos para curar heridas y a la multiplicación de los panes y los peces en el muy conocido Sermón de la Montaña. Pero no se trata de una enumeración gratuita, tampoco de un elenco de los milagros más destacados de Jesús (o quizá de una recopilación de todos ellos), sino que los seis milagros crean un punto de comparación con un nuevo milagro, el séptimo (¡y qué decir aquí a los amantes de los valores simbólicos en los números!), el último y, por eso, el más importante. También el de mayor relevancia porque se establece una suerte de cadena o de progresión que culmina en ese nuevo milagro final, que es, al mismo tiempo, una transformación del mandato-resumen del cristianismo que ya he comentado: amar al prójimo, convertido aquí en una exaltación de amor heterosexual con ciertas connotaciones pues si bien se utiliza la palabra «amar», con todas sus posibilidades, el texto supone una realización concreta y seguramente repetida con su «cada vez». Es verdad que no se habla de «hacer el amor» sino de «amar», pero la utilización de los milagros de Cristo para convertirlos en los eslabones de un proceso remite, sin lugar a dudas, a una realización muy física del amor. Y ocurre desde el primer verso donde el lector asiste a una nueva y muy erótica «transubstanciación», como cabía esperar: el sudor se convierte en vino, bebido en un beso. Como en «Aleluya n. 5 », se acumulan elementos físicos y conexos: «sed», «sudor», «pies», «lágrimas», «voz», «músculos», «latidos», «manos», «heridas», «hambre», «cuerpo», y todas estas partes o secreciones o movimientos o sensaciones componen, todas y todos juntos, el proceso que es un milagro: «cada vez que me amas». En este poema el tejido de referencias cristianas o bíblicas es particularmente intenso, intenso y transformador, pues el final implica que estos milagros conllevan el milagro final, el del amor, el de otro amor, perseguido por la repetición de un posesivo («tu», «tus») que abre hasta seis versos impares para personalizar inequívocamente el poema en ese nuevo Tú que nuclea Templo y para marcar la concreción, el hic et nunc que decían los antiguos.

Por supuesto, Templo no se agota en estas simples muestras, sino que se compone de una riquísima red de alusiones, sobreentendidos y novedades, fundidos todos por la base de la relación erótica. Buena prueba de ello es el caso del perfume. ¿Hay perfumes en ese inmenso libro que lo contiene todo, ya sea por su enorme número de páginas, ya sea porque para los creyentes es un libro inspirado, ya sea por la enorme imaginación de los exegetas que han extendido sus límites más allá de lo finito a través de los distintos tipos de interpretación? La respuesta solo puede ser afirmativa, aunque es más complicado especificar dónde, exactamente, habla la Biblia de los perfumes. Están, en mi pobre memoria, en el episodio del ungimiento de Jesús (y de otros ungimientos con aceite perfumado), y también en el lavado de pies de Cristo. 
Pero ¿hay un «sagrado perfume» en las Santas Escrituras, como indica Aute en el corte tres? 34

$$
\text { El sagrado perfume }
$$

Podría

incluso prescindir del intenso milagro

que supone descifrar

el Sagrado Perfume de los planetas...

pero nunca, nunca jamás,

del incienso que tu cuerpo despide

al cabo de la carne

comulgada.

Es una pieza breve que explota la hipérbole, tan característica de la poesía amorosa, para que el amante prefiera algo de la amada en comparación con algo de los planetas. La comparación es hiperbólica, como en tantas ocasiones en el barroco hispano, y simplemente de su planteamiento se puede deducir la fuerza del deseo del amante, mejor que la enormidad de las propias características de la amada. Cuando la comparación se explicita el lector asiste, conmocionado, a la pugna entre el «Sagrado Perfume de los planetas», del que se puede «prescindir», y «el incienso que tu cuerpo despide/al cabo de la carne/comulgada». El recurso de Luis Eduardo Aute es muy hábil, como en los poemas que ya he comentado, pues el texto explica el título, literalmente, como una referencia a la creación, aunque ¿alguien ha considerado, religiosos o filósofos, que los planetas tengan un «sagrado perfume» que hay que «descifrar»? Parecería que «El sagrado perfume» se presta a rehacer, de manera muy original, la vieja teoría pitagórica de la música del universo, de su matemática, reconvertida ahora de sonido en olor. Como en «Cada vez que me amas» el amor (la amada en este caso) triunfa de una lucha imposible (un solo ser frente a todo el universo) con un «incienso» corporal que es, a la postre, un perfume aún más sagrado que el que desprende la creación entera, con una condición: que se trate de una «carne comulgada». ¿Misticismo? ¿Misticismo erótico? ¿Erotismo?

Templo recoge muchos otros motivos que requerirían más espacio: el beso como la caída de la perfección, enfrentada en «labios contra labios» y «lenguas contra lenguas» ${ }^{35}$, un «beso que se besa» y que remite a un "círculo

${ }^{34}$ En las instrucciones para la construcción del tabernáculo se incluye lo siguiente entre las ofrendas: «aceite para las lámparas, aromas para el óleo de unción y para el incienso aromático», Éxodo 25: 6. También hay un «altar de los perfumes» y «Arón quemará en él el incienso, lo quemará todas las mañanas, al preparar las lámparas, y entre dos luces, cuando las ponga en el candelabro. Así se quemará el incienso ante Yavé perpetuamente entre vuestros descendientes. No ofreceréis sobre el altar ningún perfume profano, ni holocausto de ofrendas, ni derramaréis sobre él ninguna libación», Éxodo 30: 7-9.

35 J. I. Díez, «Pequeña puerta de coral preciado: ¿con lengua?», Caliope, 12-2, 2006, páginas 31-54. 
eterno» o al «corazón circular del Universo», que acaba en un equívoco y abarcador final, ambiguo y amplio, que enlaza con el principio: «Bésame, bésame/y dame tu nombre:/Yo, Tú, Él,/ las tres personas del Verbo» (de «No la boca sino el beso», corte seis:); el tratamiento decididamente anticristiano de elementos muy reconocibles de esa tradición (como la corona de espinas, la herida, la sangre en el costado, el dolor y la resurrección) al castigar esta peculiar resurrección — una vez enterrado «en lo más profundo de tu vientre»— con «la pena capital» (en «Descendimiento», corte siete ); la culpa (aunque es «culpa carnívora» y queda convertida en un «arcano») y la mujer y la serpiente («hembra dulce de víboras manzanas») (de «Angelus», corte ocho); la caída, la resurrección y la transfiguración (en «Irreversiblemente», corte diez, donde aparece un «amadísimo cuerpo del alma»); la levitación (de «Por donde levitas», corte doce) con ese localizador extraño y con la invitación final para que «levitemos juntos»; el estigma y la luz (el cinematográfico y negro título de «Tu sueño eterno», corte doce) ${ }^{36}$ que «me invita a traspasarte/como traspasa la luz el cristal purísimo, / sin romperlo ni mancharlo», en conocida remisión a la Peculiar Concepción; la lágrima de sangre (en «Lágrima de sangre», corte quince), que no es aquí una de las que vierte Cristo en su dolorosa pasión, sino una que el amante ve (¿dónde?) a la amada y le produce tristeza.

Frente a las canciones de neta utilización de un vocabulario religioso y cristiano se alzan dos excepciones que tienen por tema el corazón y los juegos con las frases hechas o sintagmas con «Dios». Ambos cortes («Pumpum, pumpum», nueve, e «Idiosincracia», dieciséis) ${ }^{37}$ son humorísticos (o, al menos el segundo de ellos, satírico) y delimitan un remanso que gracias a la desintoxicación de una intensa utilización de textos, relatos y leyendas cristianas permita retomar la tensión lírica. Al mismo tiempo siguen esa implacable transformación (o transubstanciación, que podría decir Aute) de los conceptos cristianos en otros, rotulados igual (la crucifixión del corazón ocurre «cuando Tú me dejas»).

Templo acaba con un doble cierre: «Al fin» y «Transfiguraciones» (cortes diecisiete y dieciocho). Propiamente el disco, como cancionero, concluye con «Al fin», pieza de extensión idéntica a «El verbo se hizo carne», que abre el trabajo. La repetición, hasta cuatro veces de «perderme» indica un método antimetódico que puede recordar, es cierto, a los místicos heterodoxos, pero esa «perdición» se realiza, circularmente, «en tu templo,/sacro cuerpo», con la finalidad de encontrarse ambiguamente «al fin», en un cierre con un sustantivo tan religioso y tan juguetón.

${ }^{36}$ Cabe aquí preguntarse, una vez más, por la procedencia religioso-cristiano-bíblica de este «sueño eterno»: solo recuerdo el sueño de los justos, aunque aquí se refiere a otra cosa, con toques ligeramente sadianos («cuando la belleza de la muerte/mana de tu anatomía,/ cada poro de tu piel, cada estigma»).

${ }^{37}$ En Templo de carne se titula «IDIOSincracia nacional». 


\section{4. ¿Mística carnal o just flesh?}

Lo que a alguno le podría sonar a sacrilegio (y seguramente de manera mucho más acusada en aquella vieja ¿y lejana? España de 1987) queda atenuado en el disco por lo dulce de la música (en ocasiones una salmodia, en otras acompañada de ecos, a veces interpretada a capella, en otras reducida a unos tambores que remiten a los pasos de Semana Santa como en «No soy digno de entrar»), el ambiente de recogimiento (una atmósfera chamánica propiamente en el segundo corte, el modulado de la voz que invita a la meditación) y por una cierta ambigüedad del tú (sobre todo al comienzo, por la sorpresa que induce un cambio tan intenso del destinatario habitual de las plegarias y oraciones). Pero es evidente que, a pesar de esos efectos, buscados tanto para explorar el paralelismo entre religión y erotismo como para remitir al sentido íntimo de casi la totalidad de los poemas, Templo es, por encima de todo, una celebración minuciosa de la erótica carnal. ¿Es también una celebración religiosa? Solo en un cierto, peculiar y muy restringido sentido: Aute reaprovecha un vocabulario, un imaginario religioso para unos fines muy distintos.

El desarrollo de un doble álbum sobre el fértil limo de un lenguaje religioso, con sus reminiscencias legendarias o evangélicas, que es del dominio público, consigue un conjunto de temas auténticamente entrelazados, unidos, con una coherencia sorprendente. El nexo sexual o erótico se combina muy bien con el lenguaje religioso desde hace siglos y en Aute lo hace con mucho gusto. Más, si se tienen en cuenta aquellas palabras sobre la estrecha conexión de Dios y el sexo («Creo que si Dios existe sería sexo puro, que no puro sexo»), pues entonces Templo se ocupa de lo central, de lo más importante. El lenguaje, las imágenes $\mathrm{y}$, sobre todo, una reorientación de la tradición, no señalan a una suerte de sexo tántrico o sexo sagrado, sino a lo sagrado del sexo en sí mismo. «Creo que el erotismo es un estado emocional fascinante», explica Aute ${ }^{38}$ y lo demuestra tanto en Templo de carne como en Templo al desarrollar en canciones de una exquisita sensibilidad la celebración del sexo entre hombre y mujer, una celebración que se vale del lenguaje universalmente extendido de la religión (cristiana o, en concreto, católica): un sexo universal con un lenguaje supuestamente universal.

$38 \mathrm{http} / / / \mathrm{www} . e l m u n d o . e s / e n c u e n t r o s / i n v i t a d o s / 2009 / 01 / 3444$ (consulta del 6 de mayo de 2016): se trata de uno de los «Encuentros digitales» de El Mundo (27/1/2009). 